\title{
CADERNO DE ESBOÇOS MM T 2784
}

\author{
Edvard Munch \\ Tradução e apresentação: \\ Ludmila Menezes Zwick
}

\section{Apresentação}

〈uma escrita diabolicamente confusa Edvard Munch

O Museu Munch de Oslo disponibiliza online a digitalização e a transcrição dos textos deixados pelo artista, dentre eles 47 cadernos de esboços. Destes, 24 não são datados; o restante apresenta datas que vão de 1876 a 1939. Um terço desses cadernos traz apenas esboços de sua obra pictórica; outro terço mescla a obra pictórica e a escrita, e o restante traz apenas textos. O conteúdo escrito desses cadernos é intimista e explicita acontecimentos da existência do artista que irão servir de referência à sua arte.

De temáticas universais e/ou contextuais, Munch extrai uma expressividade personalista, com um caráter peculiar que transcende sua adesão a movimentos ou escolas. A compreensão da obra pictórica de Munch certamente passa pela leitura do material escrito legado por esse artista, pois uma problemática essencial no estudo da pintura pauta-se no grau de subordinação da obra de arte à vida, ou seja, o que de substancial da vida imprime-se na imagem. Nesse sentido, os escritos de artistas são a fonte mais relevante para responder a essa questão, distanciando-se de um escarafunchar pautado na pura especulação da vida alheia e oferecendo bases para conjecturas sólidas.

Nesses cadernos do artista encontramos referências às suas amizades (por exemplo, com Henrik Ibsen), às suas viagens, ao simbolismo e aos demais artistas relevantes de seu tempo (como Christian Krohg), às suas avaliações de leituras e seus autores, bem como a suas relações familiares e amorosas.

O chamado caderno MM T 2784 é uma caderneta de capa azul-escuro, com 40 páginas, medindo $13 \mathrm{~cm}$ de largura por 16,5 cm de altura. Cada página tem 15 linhas e Munch as preenche irregularmente, conferindo-lhe uma aparência desordenada: ora a escrita segue as linhas horizontais, ora atravessa a página verticalmente; salta páginas; ora toma folhas inteiras, ora abandona-as com uma frase isolada. Com sentenças aparentemente soltas no ar que se condensam como nuvens, o caderno tem como fio condutor a relação do artista com Tulla Larsen.

Acerca do não datado Caderno MM T 2784, de Edvard Munch (1863-1944) - ora traduzido do norueguês -, um dos 47 cadernos que revelam em texto o que o artista produzia em imagem, são possíveis algumas ponderações. Entre 1898 e 1899, Munch foi apresentado à Mathilde (Tulla) Larsen (1869-1942); o local e as exatas circunstâncias desse encontro são um tanto imprecisos, mas, nesse período, Munch retornava ocasionalmente a Cristiânia (atual Oslo) para negócios relativos à sua arte e para visitar alguns velhos amigos da boemia. Tulla era filha de Peter Andreas Larsen, um rico

\footnotetext{
${ }^{1}$ Mestra em Estética e História da Arte pela Universidade de São Paulo e doutora em Letras (Literatura e Cultura Russa) pela mesma instituição. E-mail: apuslynx@gmail.com.
} 


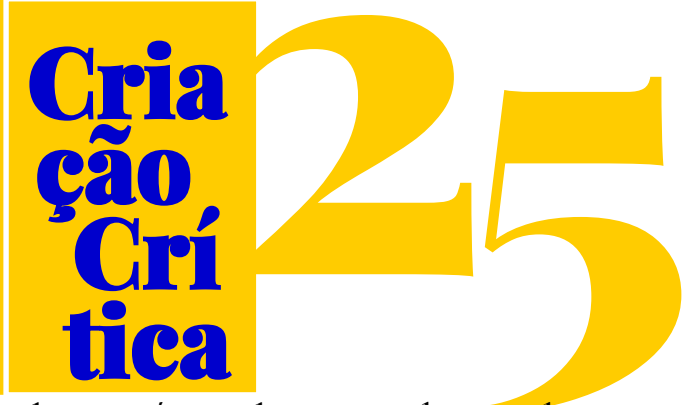

comerciante de vinhos de Cristiânia, e, graças à proeminência dos negócios do pai, tinha um lugar garantido na alta sociedade. Também artista plástica, como outras jovens suas contemporâneas (Fru Heiberg, Dagny Juell Przybyszewski e Judith Molard), Tulla desfrutava de uma existência relativamente boêmia e comportava-se de modo independente e rebelde para sua época. Seis anos mais jovem que Munch, mas frequentadora dos mesmos ambientes, os interesses comuns os aproximaram, indo do namoro ao quase casamento. O relacionamento foi conturbado, cheio de idas e vindas, e breve. Em 1902, Tulla estava determinada a casar-se com Munch em seus termos, enquanto Munch concordara em se casar, mas com certas ressalvas que se apresentariam em uma espécie de acordo pré-nupcial. As condições do matrimônio seriam árduas para Tulla, que deveria remodelar seu caráter, além de permitir que Munch fosse totalmente livre para seguir sua carreira artística como bem entendesse e que as propriedades e os bens fossem mantidos em comum. Muitos do ambiente comum de ambos apoiaram Tulla em sua hesitação.

Em 1902, ao final do verão, Munch estava em Aasgaardstrand quando uma mulher veio visitá-lo trazendo consigo uma carta da cidade vizinha de Drøbak, informando que Tulla estava para morrer e queria vê-lo uma última vez. Munch foi imediatamente, encontrando-a deitada em uma sala escura com alguns amigos. Em choque, lamentou-se, arrependeu-se e declarou seu eterno amor a ela. Contudo, ela soergueu-se saudável e vivaz, demonstrando-lhe que aquilo não passara de uma brincadeira; Munch ficou extremamente furioso. Alguns dias depois, ela o visitaria em sua casa, onde, após violenta discussão, Tulla sacou uma arma e ameaçou se matar; ao tentar desarmá-la, Munch disparou a arma e atingiu um dos dedos da mão esquerda. Mesmo tendo sido socorrido às pressas, os médicos não conseguiram salvar as duas articulações distais do dedo lesionado. Tratou-se do derradeiro confronto. Sem visitá-lo no hospital, Tulla fugiu com um pintor de vinte e cinco anos chamado Arne Kavli, com quem se casou em Paris, em 1903.

Muito do conteúdo dos escritos de Munch acerca de Tulla sofreu a influência do consumo excessivo de álcool, razão pela qual são frequentemente incoerentes e ilegíveis. A primeira correspondência de Munch para Tulla deu-se após o primeiro encontro, ainda em 1898; neste e em outras cartas, Munch dizia que ela era uma mulher com três identidades distintas e pronunciadas: a mulher melancólica e reflexiva, a virgem inocente e casta, e a semelhante à Esfinge. Na obra $A$ dança da vida (fig. 1), de 1900, Tulla serviu-lhe de modelo com suas três facetas, a da profunda tristeza, a das madonas angustiadas dos antigos pré-rafaelitas, e a irradiadora de alegria, com o rosto inundado pelo Sol, que na percepção do artista seria sua faceta mais assustadora, pois a partir desta tornava-se a esfinge, reunindo em si todas as qualidades perigosas da mulher. Ao longo do inverno de 1899-1900, Munch ficou confinado no Sanatório de Kornhaug - um sanatório para pacientes tuberculosos -, sofrendo de exaustão mental, emocional e física, período no qual escreveu muitas cartas a Tulla algumas das quais jamais enviou, cartas em que se lê o vislumbre da possibilidade do matrimônio.

\footnotetext{
${ }^{2}$ As obras produzidas entre 1900 e 1907 estão estreitamente relacionadas à Tulla. No transcurso do ano de 1899 a 1900 , Munch sofreu ataques recorrentes de bronquite ou tuberculose e pesadelos que o estavam convencendo a se casar com ela, mas também o transtornavam. Num desses, é ela uma mulher estranha com poderes hipnóticos, uma Madona. Deste, esboçou em lápis de cera o estudo que se tornaria sua obra $A$ dança da vida, de 1900 . Nesse estudo, dois cadáveres dançam a beira-mar, nas costas do cadáver feminino há uma lua cheia que reflete na água, enquanto o cabelo e o vestido da moça o enlaçam. Ao redor do casal, figuram outros dançarinos em rodopios; na obra definitiva ele incluiria mais duas mulheres: uma jovem com um vestido branco florido e de braços abertos para receber um parceiro de dança (a aspiração juvenil) e uma representação da mesma mulher já mais envelhecida e triste com um vestido preto sobre o qual ela deposita as mãos cruzadas (a resignação). Ambas contracenam com o cadáver feminino central vestido de vermelho. Dançam na obra as três personalidades que ele atribui à Tulla.
} 


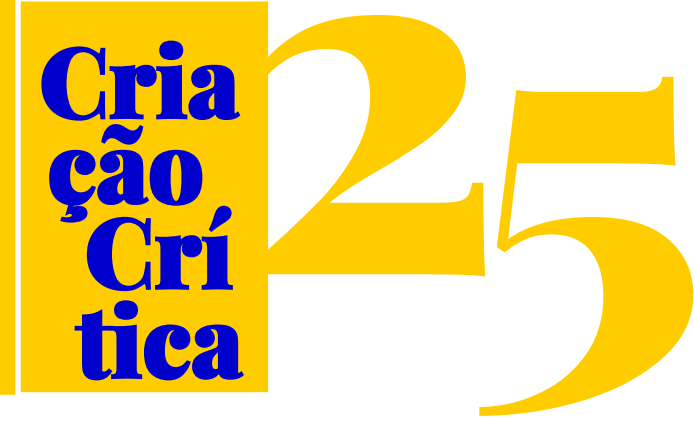

Figura 1 - Edvard Munch, A dança da vida, 1925

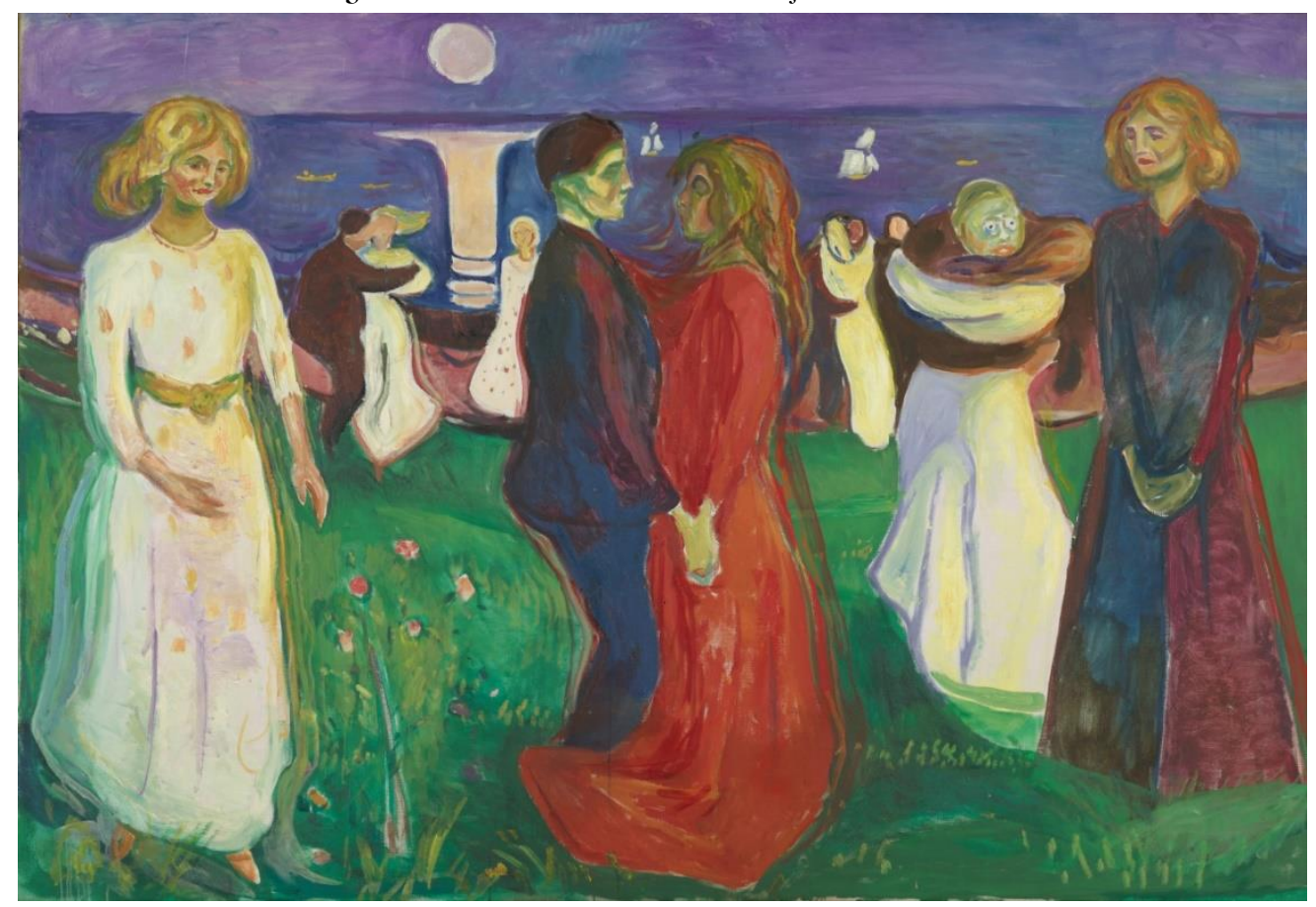

Fonte: Museu Nacional/Ove Kvavik

Munch declara-se fraco, inepto, infeliz e totalmente indigno de administrar uma casa; acreditava que suas várias doenças impediriam que ele se tornasse o marido e pai adequados. Restarlhe-ia viver uma vida solitária, sem as intempéries de uma mulher, dos filhos e de um lar. Ele se vê como um homem com uma missão, pela qual deve sacrificar suas necessidades e desejos demasiados humanos. Assim, contrapõe o casamento à arte.

O que Munch vislumbra em Tulla são características muito terrenas, enquanto sua busca seria mais espiritual; entendia que ela o destruiria espiritualmente. Por isso, o artista conclui que o sexo e o casamento deveriam ser evitados com vista à elevação do espírito. Ele julga ocupar um lugar à parte neste mundo, que lhe teria sido dado por uma vida cheia de doenças e por sua predisposição à arte, uma existência sem anseios de felicidade, e sim regulada pela solidão. De Kornhaug, sugere que ela seria a culpada de sua derrota pela doença. Após sucumbir a mais uma enfermidade nos primeiros meses do ano, apenas em março de 1900 Munch pôde viajar com Tulla para a Itália via Berlim. $\mathrm{Na}$ ocasião falaram em casamento, mas ambos persistiam tendo interesses divergentes relativos a essa questão; um tinha receio, e o outro, mais anseio de liberdade. Ao retornar à Noruega, iniciou a obra $A$ dança da vida para metaforizar de modo relativamente explícito a relação com uma mulher que tem poderes mágicos sobre ele e que por isso deveria ser eliminada, pois a permanência dela o aproximaria de sua própria morte. Assim, verificam-se na obra de Munch várias relações entre o artista e o oposto dessa temática, a dança da morte. Em sonho, ele beija os lábios pálidos e sorridentes de um cadáver.

Após uma de suas altas, Munch inebria-se de ciúmes e de ansiedade ao avistar Tulla com um homem na rua Karl Johan. Não muito tempo depois, Tulla e seu novo amante deixam Cristiânia para se casar. A partir de então, passa a responsabilizá-la por seus nervos enfraquecidos. E corta de seu convívio os amigos em comum da boemia. Assim, em extremo isolamento, desenvolveu um 


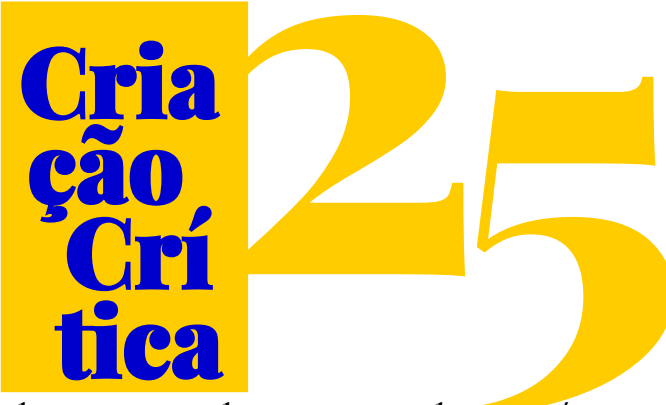

complexo de perseguição que se intensificou até levá-lo a um colapso mental e emocional; possuía a lembrança constante de Tulla a graças à lesão em sua articulação do dedo indicador e, em suas pinturas, as mãos recebem atenção peculiar e algumas vezes figuram em vermelho sangue.

O episódio da falsa doença de Tulla ainda seria mencionado por Munch em carta a Nilssen como uma armadilha repugnante que tivera a intenção de expô-lo como insano. Manifestações dessa memória dolorida sobre Tulla podem ser vista também em sua peça teatral A cidade do amor livre, na qual classifica a personagem feminina como a princesa do dinheiro, que compra as amizades e o amor, e é um demônio perseguidor, e a masculina como o pobre e indefeso menestrel que se encanta com seus beijos mortais na grande cidade. Na peça, a princesa finge que está morrendo e assim engana o menestrel, regozijando-se em lhe causar sofrimento. Por fim, o menestrel é espancado e deixado sangrando na rua; por sujar a cidade com seu sangue, ele é preso e acusado de ter causado a recusa da princesa e ter vandalizado a cidade ao sujá-la com seu sangue. O juiz então ouve a defesa do menestrel, que se depara com um sistema de amor livre ideado para defender os direitos das mulheres em detrimento dos homens. Com a concordância dos cidadãos locais, o menestrel é executado.

Em 1899, embora confinado no sanatório de Kornhaug, Munch escreveu cartas à Tulla nas quais a definia como uma Venus Vulgaris, ou seja, animalesca, terrena, comum, autoindulgente e hedonista, em suma, um ser sem alma. Por vê-la como pecaminosa, descreve-a como uma mulher cuja beleza "essencial" se perdera; um desencantamento muito peculiar a Munch, uma espécie de julgamento da mulher sob o aspecto da moralidade. Com o incidente do tiro, de setembro de 1902, deu-se o término definitivo do relacionamento entre Munch e Tulla, mas o artista continuou a descrevê-la como uma mulher vingativa, nociva e, capaz de causar sua morte.

De 1904 a 1907, Munch brigou com amigos, bebeu demais e esteve sempre à beira de um colapso nervoso; sempre com base em seu ódio, descrevia e retratava Tulla como uma assassina. A litografia A assassina, de 1904-1905, traz Munch como uma figura prostrada em um sofá. No canto da tela, uma mulher rígida mira o espectador. As mesmas personagens e espaços internos são representados na litografia Aparição, de 1906. A Tulla assassina ainda reaparece na obra $A$ morte de Marat, de 1906, na qual se vê um cadáver e uma mulher triunfante; enquanto um corpo jaz, a outra figura enfrenta o espectador da obra. Tais obras ainda se relacionam a outras por seus títulos e temáticas, como a litografia colorida A morte de Marat (A assassina), de 1906-1907 (fig. 4).

Em fins de 1906, Max Reinhardt encarregou Munch de projetar cenários para a produção do drama em quatro atos de Henrik Ibsen, Hedda Gabler (1891), que estreou em março de 1907 no Teatro Kammerspiele, em Berlim. Muito familiarizado com a peça de Ibsen, o artista deixou Bad Kosen, na Alemanha, onde residia, e chegou à capital alemã em novembro, onde colaborou com diretor de cenário Hermann Bahr enquanto participava dos ensaios e fazia seus esboços. Contudo, problemas de saúde o forçaram a retornar a Bad Kosen no início do ano seguinte. Seguindo sérias restrições médicas para acalmar seus nervos desgastados, o artista completou seus esboços para Reinhardt e Bahr, entre os quais estava o esboço de Hedda Gabler. Há certa parecença entre o papel de Tulla ${ }^{3}$ na vida de Munch e o de Hedda na de seu ex-pretendente no drama de Ibsen.

A morte de Marat, de 1907 (fig. 5), reitera a ideia de Tulla como um anjo assassino e vingador. A mulher verticalizada e o homem horizontal são perpendiculares. Sobre a versão de 1907, Munch escrevera que havia demorado muito tempo para se recuperar daquela imagem, que, a seu ver, fora uma vitória sobre essa mulher. O artista revela ter carregado tal tema dentro de si ao longo de longos

\footnotetext{
${ }^{3}$ Ainda dando expressão ao tema da traição de uma mulher e inspirado na obra de Lucio Apuleio, escrita durante o século II, pintou Amor e Psique, em 1907, durante os meses de verão e outono, quando tentava recuperar-se do alcoolismo e da exaustão nervosa.
} 
Literatura e artes visuais: entre o lisível e o visível

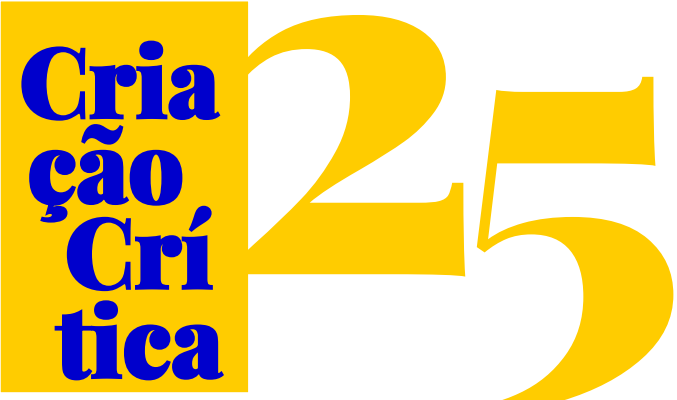

nove anos; a obra foi exibida no Salon des Independants, de 1908, e, alguns meses depois, ele internava-se voluntariamente na clínica do dr. Jacobson, em Copenhague, por exaustão nervosa.

Figura 2 - Edvard Munch, Tulla Larsen, 1898-99

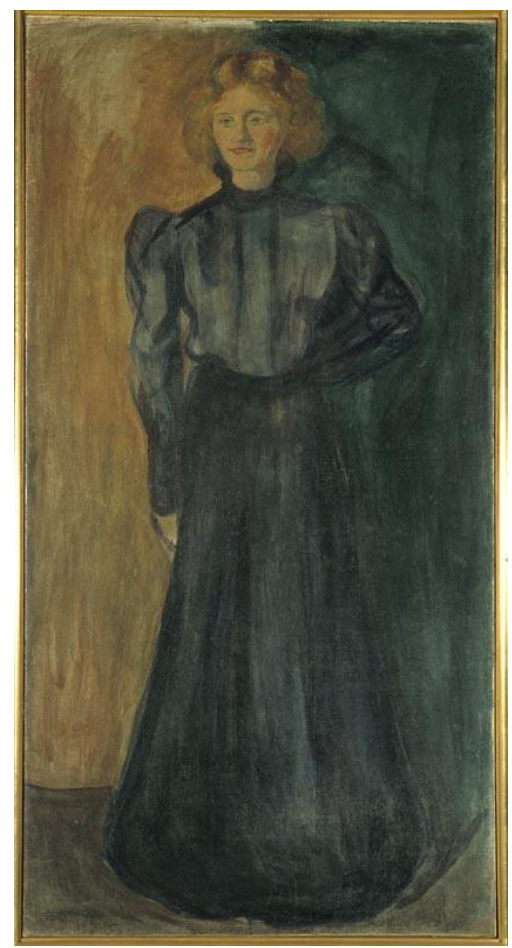

Fonte: Museu Nacional/Sidsel de Jong

Figura 3 - Edvard Munch, Retrato caricatural de Tulla Larsen Larsen, 1905

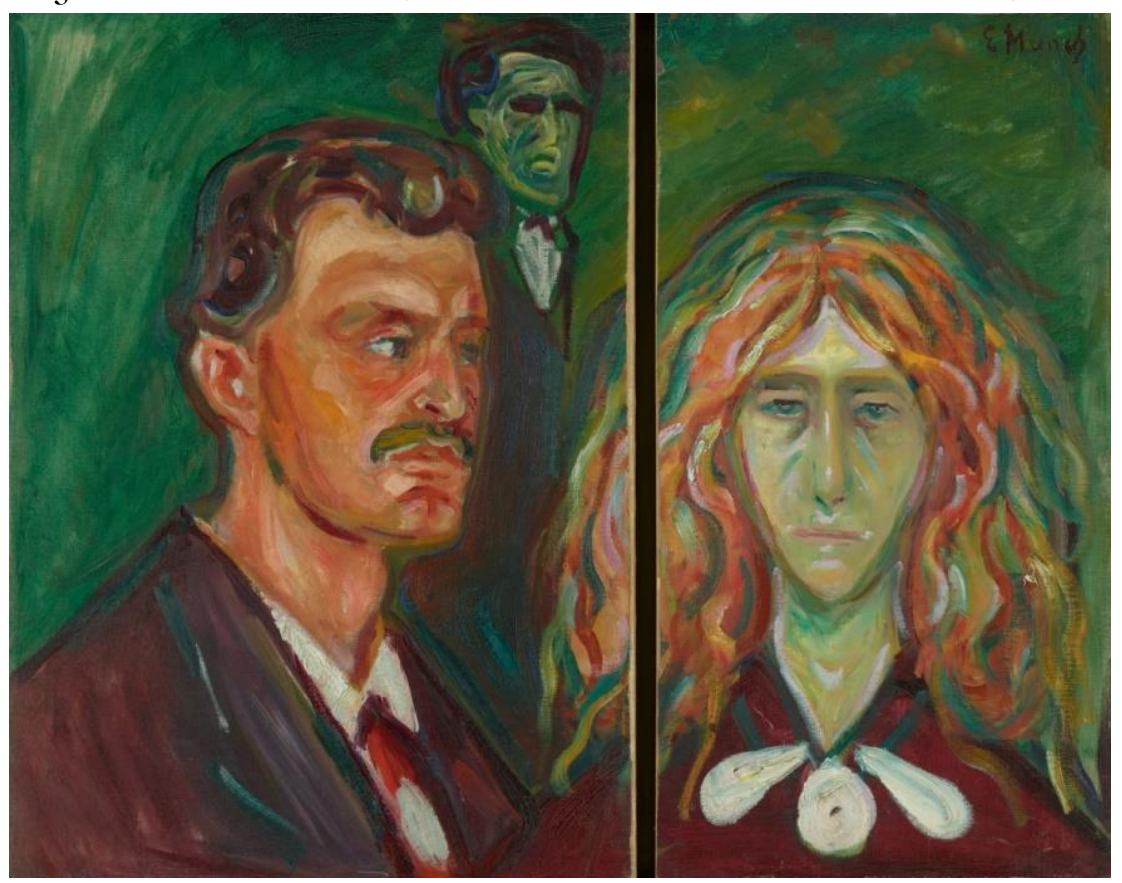

Fonte: Museu Nacional/Ove Kvavik 


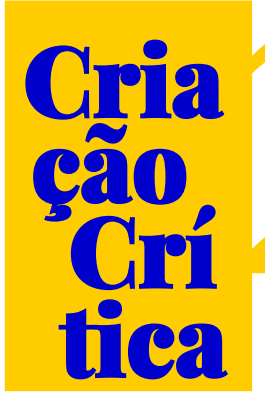

Figura 6 - Edvard Munch, Primeira e quarta capas do caderno de esboços MM T 2784
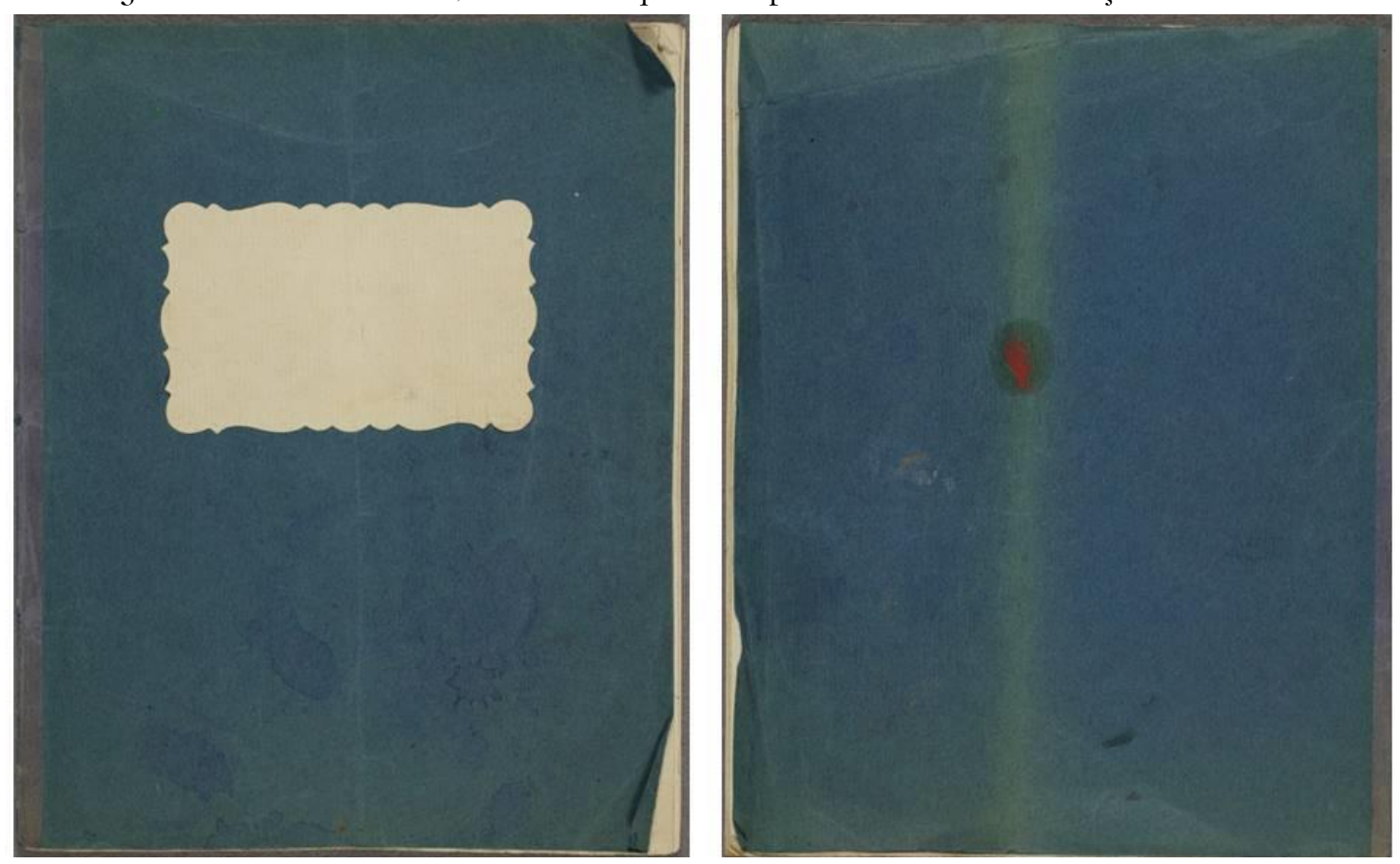

Fonte: Museu Munch

\section{O cadlerno MM T 2784 4}

\section{p. 1}

Chegou uma carta -

A sra. $L^{5}$ jaz doente - Venha imediatamente -

Eu lhe imploro - esta noite elisse me despertou e disse - não acredito

que ele venha - estou

tão infeliz - Uma meia hora

depois ouvi um gemido - eu

entro - e a encontro

muito doente - na mesa havia

frascos de morfina vazios - Ela estava

gelada - acreditei que ela

\footnotetext{
${ }^{4}$ Embora as páginas sejam contadas de 1 a 40, o texto não é contínuo, pois há paginas em branco e outras com rasgos, a exemplo das páginas 15 e 17, o que impossibilita a leitura. O ordenamento de páginas segue a paginação a lápis feita por Munch nas folhas do caderno, com exceção dos casos em que as anotações saltam páginas. Por exemplo: a "oficial" página 3 é a sequência da primeira página e não da segunda, já que o texto ainda trata do mesmo assunto, ou a página 28 que dá sequência à página 30. Em seu esforço literário, Munch revela personagens ("ele", Brandt) que se relacionam com ele próprio, com suas experiências e aspirações.

${ }^{5}$ Refere-se à Tulla Larsen, no acervo digital do Museu Munch somam-se 83 cartas e rascunhos de cartas para ela, também chamada por Munch de Tullik.
} 
morreria - Ela proferiu seu

nome - Dei-lhe café

como antídoto - e ela vomitou

a noite inteira -

\section{p. 3}

ela está melhor - mas venha

imediatamente - esperança de salvá-la

- Ele segurou a carta nas

mãos, sobressaltado - e aturdido -

- Ela o ama - realmente

até a morte - e agora ela jaz

à beira da morte - porque ela não

pode viver sem - ele -

- Ela deve estar sofrendo terrivelmente -

- e ele esqueceu tudo o que

aguentara - e que

considerou vil da parte dela

\section{p. 5}

\section{Homansbyen $^{6}$}

O velho se lembra agora de tudo o que ela fez contra - Elas o ludibriaram - o difamaram As mulheres são tirânicas - ao não conseguir o que querem, elas gritam até conseguirem os brinquedos que irão jogar fora -

Sim, mas quando não é possível outra coisa senão tentar ajudá-la - quando ela jaz e deve morrer Oh, deixe-a morrer Viaje para a Alemanha -

Penso

Se

\footnotetext{
${ }^{6}$ Nome de um bairro exclusivamente residencial em Olso, dado em homenagem aos irmãos advogados Jacob (1816-1868) e Henrik Homan (1824-1900).
} 


\section{S}

Se se chegar a um acordo eu gostaria de reunir uma pequena coleção de pinturas (cerca de 10 obras) e uma coleção de 20 ou 30 gravuras fazer uma turnê pelas pequenas cidades da Noruega -

Para que isso possa acontecer, gostaria de sugerir que se garantisse uma venda de pelo menos 200 coroas pelas gravuras O que possivelmente 〈é〉

p. 14

Estejam cientes

minha arte está em tão grande disputa com o gosto do público que devo tentar fazer meus trabalhos desse modo bl ... fora $\mathrm{m}$

p. 19

Enfim chegou a primavera Sel Quando o Sol apareceu brilhou mais e mais -

- Mas o frio e a neve do Norte não quiseram soltar - não quiseram abandonar a Terra gélida - sobre a qual reinaram por muitos meses - Grandes massas de tropas escuras se achavam persistente e ameaçadoramente atrás das colinas do Norte sobre Frognersceteren

- A $\{\ldots\}$ As escuras

nuvens invernais

detiram-se lá atrás quando o Sol arde, mas arremetem 
p. 21

novamente ao longo da tarde

- Cobrindo todo o céu -

Lá rumo ao Sul - Nuvens de contos

de fadas brilham com os ventos do sul

e o Sol da Itália - castelos de nuvens

ardentes como o Sol -

Eles permanecem lá e esperam por

poder chegar e derramar seu

calor sobre a terra gélida -

e adquirir força para afugentar

- as nuvens invernais -

- À tarde, quando o Sol

está alto - elas debandam suas angelicais

nuvens brancas - pelo

ar azul brilhante - Um vento

p. 23

quente da Itália tornou 〈sua〉

mente fraca - e estranhamente melancólica -

- A neve derreteu os riachos

correu dos telhados ... gotejou

cintilantes pérolas de água -

A terra amoleceu -

A primavera chegou -

Mas, durante a tarde,

cerraram-se de ódio e despeito

os grandes punhos azuis-pretos

- cinza-chumbo das nuvens invernais e dominaram

com força renovada sobre

a abóboda celeste - e as angelicais

nuvens do Sul - são afugentadas 
Figura 7 - Edvard Munch, único desenho do caderno de esboços MM T 2784

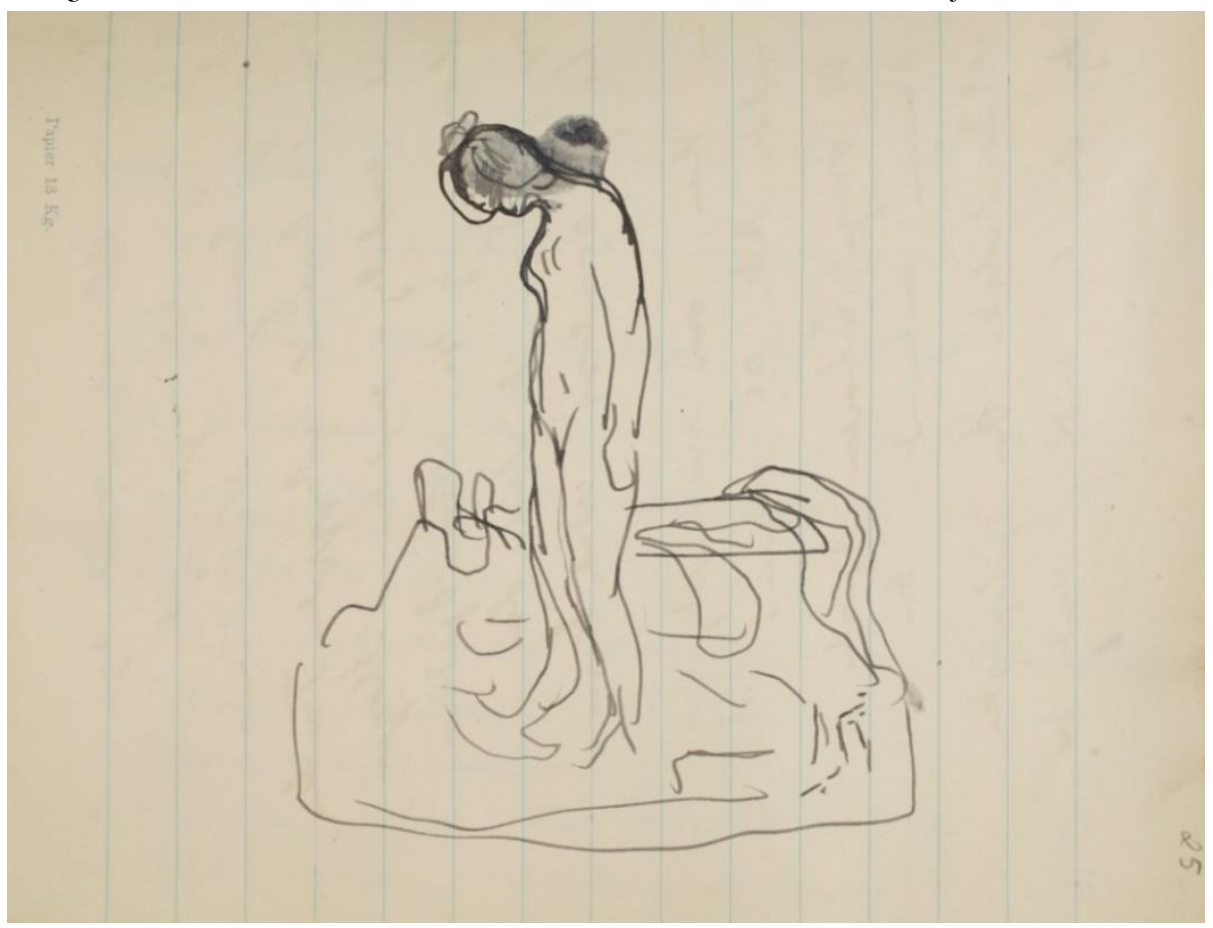

Fonte: Museu Munch

p. 32

O distraído -

Está sempre sentado e diz - pagar

- paga e se esquece -

ei, garçom - ele paga -

até que seu bolso esteja vazio de dinheiro

- Ei, garçom - uma cerveja -

Incessantemente - por fim, sem

olhar para cima, mas apenas com um movimento de mão

- acenando para o garçom - e

apontando para o copo vazio

Ele cai da cadeira -

p. 30

A casa amarela

- A casa de madeira amarela envernizada com dois pisos - e uma varanda na frente. De mau gosto - com feias volutas de madeira entalhadas - e estúpido estilo de dragão 
Uma cor amarela envernizada e pegadiça

que ... produzia um efeito triste contra a

floresta escura -

Lá em cima, no segundo andar, ele

tinha dois quartos pequenos -

amarelos pegadiços envernizados $\langle\mathrm{e}\rangle$ - tristes e de mau gosto

Mas a vista para o fiorde

p. 28

com copas de abetos à frente

e ilhotas ao longe

era bela - melancelicamente tristemente

bela -

- Ali nos dois quartos

ele caminha para cá e para lá - é

para cá e para lá - então, um longo passeio

- então, de novo para cá e para lá pelo quarto

até chegar a hora de dormir - Como ele

odeia a cama - seu cavalete de tortura

- lá ele se deita - para

cair no sono - e, outra vez desperto, despertissimo

- Era de manhã - ele olha para o

relógio 1 «não〉-apenas 1 hora de sono

p. 26

Então ele fica a virar-se

revolver-se na cama - as

longas, longas horas noturnas

com mil pensamentos lúgubres

até que por fim - por fim - a manhã

chegou - e então, outra vez, as andanças

para lá e para cá - até que outra longa

noite em branco chegou -

- Ele era misantropo -

não queria ver ninguém -

Os demais moradores comiam

juntos no andar de baixo. $\mathrm{O}$

melancólico, o epilético

e todos os outros - Abaixo dele 
p. 24

a proprietária jazia com as

pernas paralisadas

p. 27

Ele esperou a primavera e o verão

- assim sua bronquite poderia se curar -

e o sono e a saúde voltariam outra vez -

Quando as negras nuvens de neve do Norte prevaleceram - assim ${ }^{\text {por }}$ diversos dias nevou choveu ventou - ele adoeceu - e tão fatigado

que mal podia andar -

Ele se deparou com $\theta$ o

- comerciante $\ldots$ tísico -

- que morava na vila ao lado-

- Quantos caminhos

Agora eu epenhei fiquei resfriado ele disse -

fiquei deitado por 5 dias - escarrar o dia inteiro

p. 29

- E não posso comer - apenas vomitar

Qual é o seu peso -

Eu peso apenas $110^{7}$ - como uma criança -

- Quem dera chegasse a primavera

Visitei o no dia seguinte-

Visitei-o no dia seguinte

- Ele estava sentado à escrivaninha -

Estou apenas escrevendo meu testamento -

Não temos filhos - e «minha esposa deve herdar -

- Soube que ele vinha escrevendo esses testamentos há 2 anos

p. 31

Quando a esposa fora boa para

ele escreveu ele legou a casa em testamento para a esposa -

Quando ela o irritou

ele rasgou o testamento em pedaços -

- Ele, tão mal, cuspiu num

copo ao seu lado que estava cheio de

escarro -

${ }^{7}$ Provavelmente libras, unidade de peso histórica definida por cerca de 500 gramas. Em torno de 55 quilos. 
Brandt $^{8}$ falou algumas palavras e saiu em seguida -

p. 33

Ele deu um passeio pela

escura floresta de abetos - ... e então foi

para casa, para seu quarto -

- Chegou uma carta da proprietária

-- E o senhor faria a gentileza de verificar

a conta - ela gostaria de receber o dinheiro

agora

- De mais a mais, ela está muito mal - talvez

não 〈sobreviva〉

B. ${ }^{9}$ pagou e enviou saudações -

- Ela enviou a mensagem e retribuiu as saudações e agradeceu

À noite, estava morta

p. 2

No dia seguinte, Brandt ${ }^{10}$ acordou -

- saiu para a varanda

A primavera chegara -

- Água branco-douradas

Nuvens da terra do reino do Sol ...

afugentam as potências das geleiras do norte

para as montanhas - <para Jotunheimen - e Rondane

- A natureza sorriu - O fiorde lá fora,

arejadas colinas azuis - As copas dos abetos

e todo o verde germinante -

- Brandt saiu -

Um caixão era colocado num veículo - e proprietéria

Era a proprietária - Ela pediu para ser

levada imediatamente à cidade, para não estar presente

Importunar os hóspedes

\section{p. 35}

Essa beberagem do inferno preparada

com sangue de plantas viníferas

\footnotetext{
${ }^{8}$ Vide nota 6.

${ }^{9}$ Vide nota 6.

${ }^{10}$ Personagem literária provavelmente baseada em Edvard Munch que aparece com diferentes nomes: Erik, Kristian e Bernhard.
} 
- misturada com veneno de mulheres

vampiras - Era uma beberagem

escaldante - na Maquinaria do cérebro e tinhe ${ }^{\text {onde }}$

Eu nãoseubom nisse

o tecido celular cerebral se expande

na aquecida e inchada parede celular

<uma escrita diabolicamente confusa

inscrita como em um fonógrafo -

- O tecido celular que foi expandido

como um balão tensionado ao

máximo - murchou como

uma folha amarrotada - para então outra vez

p. 36

ser fervido e expandido - $\{\ldots\}$ queimar

e gritar num coro de diabos

do inferno - e a cremação

dos cadáveres de plantas

- o tabaco enviou suas

atordoadoras e tóxicas cinzas

- que empestaram a atmosfera sabre eerebral

sobre o tecido celular ferido

- para dentro dos feridos e sangrentos

corredores e labirintos do crânio

p. 37

Ele estava sentado no meio de um grande

Café abarrotado - olhando fixamente

Lá (fora)... para o espaço

... Ele Tão logo ele

esvaziara um copo - disse sem olhar

para o garçom - Outro copo e

um charuto -

Por fim, ele apenas fazia um

movimento com a mão e lá

vinham um novo copo e um novo charuto

- Olsen ${ }^{11}$ chegou - Ouve,

a senhorita pediu-me para dizer que

gostaria de comprar uma pintura

${ }^{11}$ Homem não identificado; muitas cartas possuem destinatários não identificados, classificados pelo museu como homem, mulher ou pessoa não identificada. 
tua - Ela vê ... e

casa-se com Kavli ${ }^{12}$

Gunnar Heiberg ${ }^{13} \mathrm{e} \mathrm{SB}^{14}$

p. 39

O sangue afluiu à sua

cabeça - Uma diabólica

combinação de tabaco, de vinho

$-\mathrm{e}^{\text {diabolismo }}$ feminino inflou

seu tecido celular -

balão inflamado - e uma

música infernal começou

- Ele viu o rosto de um homem

olhando fixamente em sua

direção -

Ele ergueu uma mão

sangrante no ar -

Ele estava na rua

p. 40

Minha alma são apenas dois cavalos selvagens

que me dilaceram, cada qual para seu canto

Schiefler ${ }^{15}$ e uma porção de

Folhas para o envio

Uma ave de rapina cravou

suas garras em meu coração.

seu bico talhou um buraco

em meu peito

- seu bater de asas tem

obscurecido meu entendimento

- Minha alma está cindida

em duas - como pombas selvagens

que voam cada qual para seu lado

Estais meramente em meu pobre

cérebro hemorrágico

Sois uma imagem inscrita em

meu <tecido celular exaltado

\footnotetext{
${ }^{12}$ Arne Texnes Kavli (1878-1970): pintor e gravurista norueguês. Casado com Mathilde "Tulla" Larsen de 1903 a 1910.

${ }^{13}$ Gunnar Edvard Rode Heiberg (1857-1929): escritor e dramaturgo norueguês, primo do poeta Helge Rode. O sobrenome Heiberg foi mais tarde vinculado por Munch a "inimigo".

${ }^{14}$ Sigurd Bødtker (1866-1928): escritor e crítico de teatro norueguês. Cunhado de Gunnar Heiberg.

${ }^{15}$ Gustav Schiefler (1857-1935): jurista, colecionador de arte, mecenas e crítico de arte alemão. Retratado por Munch.
} 


\section{Referências}

Escritos de Edvard Munch. Acervo digital, publicado pelo Museu Munch. Coleção de Cadernos de esboços. MM T 2784, p. 1-40, s/d. Disponível em: <https://www. emunch.no/HYBRIDNoMM_T2784.xhtml>. Acesso de: ago. de 2018 a jun. de 2019.

Munch, E. A dança da vida, 1925, óleo sobre tela, 143 x 208 cm. Museu Nacional, Coleção de Artes Visuais, $\mathrm{n}^{\mathrm{o}}$ de inventário: MM.M.00777. Tøyengata 53, 0578 Oslo, Noruega. Foto: Museu Nacional/Ove Kvavik.

Tulla Larsen, 1898-99, óleo sobre tela, 119,5 x $61 \mathrm{~cm}$. Museu Nacional, Coleção de Artes Visuais, $\mathrm{n}^{\mathrm{o}}$ de inventário MM.M.00740. Tøyengata 53, 0578 Oslo, Noruega. Foto: Museu Nacional/Sidsel de Jong.

. Retrato caricatural de Tulla Larsen Larsen, 1905, óleo sobre tela, 62 x $33 \mathrm{~cm}$. Museu Nacional, Coleção de Artes Visuais, no de inventário: MM.M.00345. Tøyengata 53, 0578 Oslo, Noruega. Foto: Museu Nacional/Ove Kvavik.

. A morte de Marat, 1906-1907, litografia, 435 x 353 mm. Museu Nacional, Coleção de Artes Visuais, $\mathrm{n}^{-}$de inventário: NG.K\&H.A.19009. Tøyengata 53, 0578 Oslo, Noruega. Foto: Museu Nacional/Dag Andre Ivarsøy.

. A morte de Marat, 1907, óleo sobre tela, 27,8 cm x 20,9 cm. Museu Nacional, Coleção de Artes Visuais, $\mathrm{n}^{\mathrm{o}}$ de inventário: MM.M.00351. Tøyengata 53, 0578 Oslo, Noruega. Foto: Museu Nacional/Richard Jeffries. 